\title{
Glioblastoma Masquerading as a Parafalcine Meningioma: A Pathological Surprise!
}

\author{
Anoop Varma1 Chittur Viswanathan Gopala
${ }^{1}$ Department of Neurosciences, Aster Medcity, Kochi, India
2Department of Pathology, Aster Medcity, Kochi, India
}

J Neurosci Rural Pract 2020;11:668-669

A 30-year-old female presented with an acute history of left-sided focal seizures with secondary generalization. Magnetic resonance imaging (MRI) of the brain (-Fig. 1) revealed a large tumor attached to mid one-third of the falx cerebri with extension to either sides, a heterogeneous contrast enhancement (-Fig. 1D and E) and presence of extensive peritumoral edema. A provisional diagnosis of mid one-third falx meningioma was made, and the patient underwent bifrontal craniotomy and excision of the lesion.

Intraoperatively, the tumor was greyish, soft to firm, vascular, and adherent to the falx. The pial plane between the tumor and the parenchyma was breached along with multiple pial feeders. The falx was excised along with the tumor.

The histopathology showed a cellular neoplasm attached to the dural collagen ( - Fig. 2A) with highly pleomorphic cells, hyperchromatic nuclei, intranuclear pseudoinclusions, and fibrillary cytoplasm with atypical mitosis (-Fig. 2b) and necrosis. The immunohistochemistry showed strong glial fibrillary acidic protein and S-100 in tumor cells with coexpression of epithelial membrane antigen and retained nuclear ATRX (alpha thalassemia/ mental retardation syndrome $\mathrm{X}$ linked gene mutation) gene mutation. In immunohistochemistry, IDH1 (R132H) was negative and $\mathrm{p} 53$ was not expressed. The $\mathrm{K}_{\mathrm{i}}-67$ proliferation index was $30 \%$. The diagnosis of glioblastoma multiforme, isocitrate dehydrogenase-wild type, World Health Organization grade IV was confirmed.

As originally proposed by Cushing, falx meningiomas are tumors arising from the falx cerebri covered by the overlying cortex. ${ }^{1}$ Falx meningiomas predominately have a propensity for unilateral extension but can often be bilateral and dumb-bell shaped. ${ }^{2}$ Falx meningiomas are divided into two types: internal and external. The former originates from the inferior sagittal sinus and the later from the body of the falx. ${ }^{3}$

There have been case reports in literature where glioblastoma multiforme (GBMs) at different locations have mimicked a meningioma on imaging. ${ }^{4}$ Many of the times, it is often an intraoperative and pathological surprise. In MRI, meningiomas and GBMs can often be differentiated due to their characteristic appearances (-Table $\mathbf{1}$ ). But rarely one may mimic the other causing a pathological surprise.

In our case, on retrospective review of the images, there were some points against a diagnosis of an extra-axial lesion. The symmetrical extent of the tumor on either side of the falx, the extensive pial breach especially in the anterior cingulate, the heterogeneity on contrast possibly suggesting areas of necrosis, and nonvisualization of a definite cerebrospinal fluid cleft surrounding the tumor should have raised the suspicion of a high grade intrinsic tumor preoperatively. The prognosis of these two totally diverse pathological entities is different, and therefore, the recognition is of utmost importance. It helps in surgical planning and patient counseling prior to surgery.

This report highlights the importance of keeping in mind a differential diagnosis of an alternate pathology when the MRI features are ambiguous. Additional MRI sequences like magnetic resonance spectroscopy and MR perfusion can often help in clinching the diagnosis preoperatively rather than a histological surprise later on. 

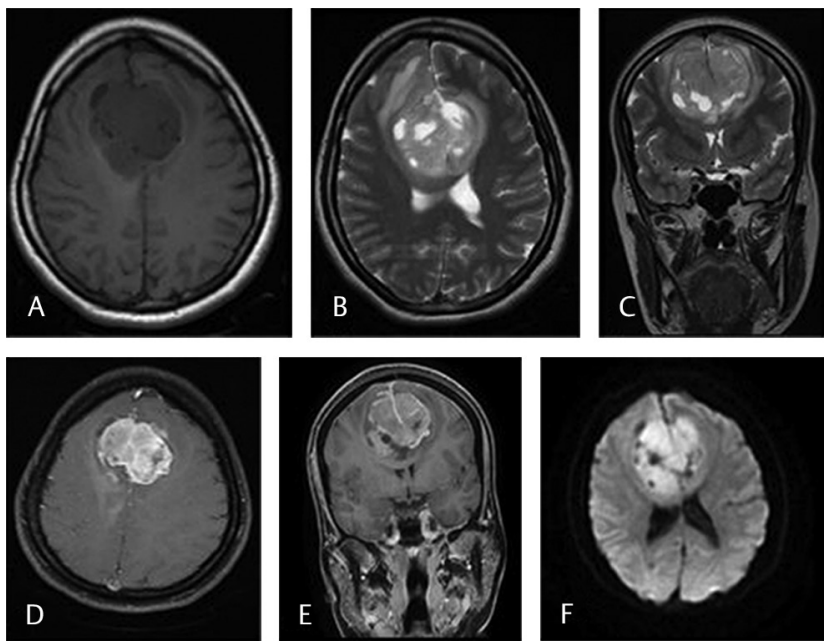

Fig. $1 \mathrm{~T} 1$ (A) and T2 (B) weighted axial MRI show a large heterogeneous tumor encasing the falx and extending into both the cerebral hemispheres. There is perilesional edema with buckling of the cortex on coronal T2W (C) image. The attachment to the falx with its enhancement is seen in postcontrast T1W axial (D) and coronal (E) MRI. Diffusion weighted imaging (F) shows areas of restricted diffusion within the tumor. MRI, magnetic resonance imaging.
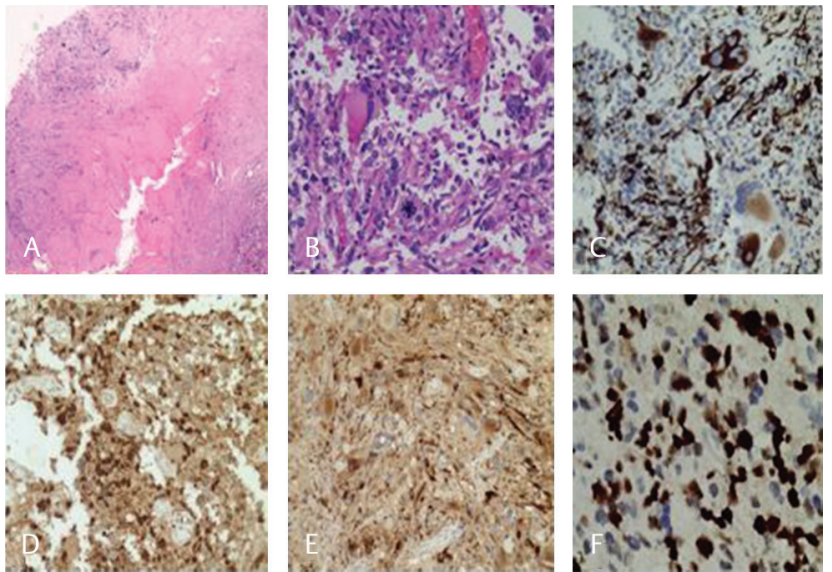

Fig. 2 Cellular neoplasm attached to dural collagen $(\mathbf{A}, \mathrm{H} \& \mathrm{E}, \times 20)$; markedly pleomorphic cells with atypical mitosis (B, H\&E $\times 400$ ); immunohistochemical expression of glial fibrillary acidic protein in tumor cells (C); S-100, (D) epithelial membrane antigen (E) and high MIB-1 proliferation index (F). H\&E, hematoxylin and eosin.

\section{Note}

The work was primarily performed at Aster Medcity, Kochi, Kerala.

\section{Conflict of Interest}

None declared.
Table 1 Differences between meningioma and glioblastoma based on magnetic resonance imaging

\begin{tabular}{|c|c|c|}
\hline $\begin{array}{l}\text { Radiologic } \\
\text { features on } \\
\text { MRI }\end{array}$ & Meningioma & Glioblastoma \\
\hline General & $\begin{array}{l}\text { Well-defined } \\
\text { extra-axial tumor }\end{array}$ & $\begin{array}{l}\text { Intra-axial irregular } \\
\text { mass }\end{array}$ \\
\hline $\begin{array}{l}\text { Extra-axial mass } \\
\text { vs. intra-axial } \\
\text { mass }\end{array}$ & $\begin{array}{l}\text { CSF cleft sign } \\
\text { Broad dural base } \\
\text { Displaced } \\
\text { subarachnoid vessels } \\
\text { Bony hyperostosis } \\
\text { Expand subarachnoid } \\
\text { space } \\
\text { White matter } \\
\text { buckling sign }\end{array}$ & $\begin{array}{l}\text { Thickened } \\
\text { nonenhancing cortex } \\
\text { with increased T2 } \\
\text { signal } \\
\text { Expansion of nearby } \\
\text { gyri (this is the } \\
\text { opposite of the white } \\
\text { matter buckling sign) } \\
\text { Thickening of the } \\
\text { corpus callosum }\end{array}$ \\
\hline $\begin{array}{l}\text { On contrast } \\
\text { administration }\end{array}$ & $\begin{array}{l}\text { Uniform contrast } \\
\text { enhancement }\end{array}$ & $\begin{array}{l}\text { Ring enhanc- } \\
\text { ing contrast } \\
\text { enhancement with } \\
\text { central necrosis }\end{array}$ \\
\hline $\begin{array}{l}\text { Vasogenic } \\
\text { edema }\end{array}$ & Can be present & $\begin{array}{l}\text { Profound vasogenic } \\
\text { edema }\end{array}$ \\
\hline Bony changes & $\begin{array}{l}\text { Bone hyperostosis } \\
\text { and meninges show } \\
\text { dural tail sign }\end{array}$ & $\begin{array}{l}\text { No obvious bony } \\
\text { changes }\end{array}$ \\
\hline Midline crossing & $\begin{array}{l}\text { Can involve the } \\
\text { meninges causing } \\
\text { contralateral } \\
\text { extension }\end{array}$ & $\begin{array}{l}\text { Can involve the } \\
\text { corpus callosum } \\
\text { and spread to the } \\
\text { opposite side }\end{array}$ \\
\hline $\begin{array}{l}\text { Local tumor } \\
\text { spread }\end{array}$ & $\begin{array}{l}\text { Pressure effect on the } \\
\text { surrounding brain is } \\
\text { more }\end{array}$ & $\begin{array}{l}\text { Less pressure effect } \\
\text { in comparison to } \\
\text { their size }\end{array}$ \\
\hline
\end{tabular}

Abbreviations: CSF, cerebrospinal fluid; MRI, magnetic resonance imaging.

\section{References}

1 Cushing H, Eisenhardt L, Their classification, regional behavior, life history, and surgical end results. Bull Med Libr Assoc1938;27(2):185

2 Chung SB, Kim CY, Park CK, Kim DG, Jung HW. Falx meningiomas: surgical results and lessons learned from 68 cases. J Korean Neurosurg Soc 2007;42(4):276-280

3 Yasargil MG, Microneurosurgery of CNS Tumors, IV-B. Stuttgart: Georg Thiem Verlag; 1996 134-165

4 Patel M, Nguyen HS, Doan N, Gelsomino M, Shabani S, Mueller W. Glioblastoma mimicking meningioma: report of 2 cases. World Neurosurg 2016;95:624.e9-624.e13

5 Smithuis R, Montanera W. The radiology assistant: systematic approach. radiologyassistant. Available at: https://radiologyassistant.nl/neuroradiology/brain-tumor/systematic-approach. Published 2008 